\title{
HR BRANDING AND THE POTENTIAL VALUE: EMPIRICAL EVIDENCE AND PRACTICAL IMPLICATIONS
}

\author{
Stojan Debarliev \\ Faculty of Economics-Skopje, Ss. Cyril and Methodius University in Skopje, Republic of North Macedonia \\ stojan@eccf.ukim.edu.mk
}

\section{Ezeni Brzovska}

Faculty of Economics-Skopje, Ss. Cyril and Methodius University in Skopje, Republic of North Macedonia ezeni@eccf.ukim.edu.mk

\section{Aleksandra Janeska - lliev}

Faculty of Economics-Skopje, Ss. Cyril and Methodius University in Skopje, Republic of North Macedonia aleksandra@eccf.ukim.edu.mk

\begin{abstract}
Despite the growing popularity of the employer branding concept, academic research on the topic is limited; this is pivotal and pioneer research in the Republic of North Macedonia. This research investigates the possible factors that might affect the specific dimensions of firms' HR branding, such as employer branding, internal branding, and total rewards branding. Different parametric and non-parametric tests were run to determine if there were group differences in employer branding, internal branding, and total rewards branding scores between groups within eight evaluated variables divided into three categories: demographics of respondents (age, gender, and educational level), firm characteristics (size, industry sector, and ownership origin), and professional characteristics of respondents (job level position and customer contact level). The results confirm the expected differences in some of the evaluated HR branding dimensions between employees with different professional characteristics (job level position and customer contact level).
\end{abstract}

Keyword: HR branding, employer branding, internal branding, total rewards branding

\section{INTRODUCTION}

Branding was originally used to differentiate tangible products, but has diversified in many new directions: people, places, and firms (Peters, 1999). The term has been evolving over time and expanding the usage in various contexts. Just as branding applies to products or services, branding may also affect firms' human capital by adding value to the employment experience of current and prospective employees (Enz, 2001). The employer brand strives to build an image for the company as an employer of choice by creating a good reputation and showing the company as a great place to work (Sullivan, 2004). HR branding, and especially internal branding, is defined as a set of strategic processes that empower employees to "live the brand" (Khan, 2009). A growing number of authors have indicated their interest in and dedication toward this topic (Cable \& Turban, 2001; Davies, 2008; Wilden, Gudergan, \& Lings, 2010; Sivertzen, Nilsen \& Olafsen, 2013; Rieches, 2017).

Wilden, Gudergan, \& Lings (2010) proposed an employee-based brand equity model and stated the need to link psychological, economic, and functional 
benefits that potential employees associate with a certain company. Certain conceptual models confirmed the correlation between employee productivity and employer attractiveness, emphasizing the need to create a desirable brand for the employers (Leekha, Chhabra \& Sharma, 2014). Therefore, the employer brand concept has evolved into a holistic discipline and should encourage co-creation, negotiation, and performance of new sustainable relationships between the company and its potential and current employees (Kryger, Esmann \& Thomsen, 2011).

Despite the growing popularity of the employer branding concept, academic research on the topic is limited, and this is pivotal and pioneer research in the Republic of North Macedonia. Companies should communicate their unique value proposition by coordinating HR functions with marketing tactics (Kim \& Sturman, 2012). Because employer branding is a complex process, it requires interdepartmental inputs and a holistic view of different components. By employing a broader holistic approach, companies increase employee commitment and emotional attachment to the corporate brand.

Before investigating the deeper aspects of $\mathrm{HR}$ branding, the possible factors that are not directly related to the companies' activities to create and maintain strong HR brands but that might affect the effectiveness of these efforts should be examined. Because this has not been investigated, we found a need to conduct exploratory research considering some basic characteristics that could have high potential for influence. These characteristics are related to employees' demographic background, such as age, gender, and educational level, as well as to a firm's background, such as size, industry sector, and ownership origin. The employees at higher job position levels are those who develop the HR brand and should be more aware of the HR brand and perceive differently its manifestations. Furthermore, employees with direct contact with customers are very often more familiar with and have greater awareness of the core values of the corporate brand because they are in everyday contact with customers, delivering the brand promise to them. Hence, in addition to the two basic characteristics, we added a third, more specific characteristic related to the professional background of respondents, such as job position level and customer contact level.
This research investigates the possible factors that might affect specific dimensions of firms' HR branding, such as employer branding, internal branding, and total rewards branding. In particular, this research examines eight different factors, divided into three categories: demographics of respondents (age, gender, and educational level), firm characteristics (size, industry sector, and ownership origin), and professional characteristics of respondents (job position level and customer contact level).

Hence, the main research question is: Is there a difference in HR branding dimensions among employees' (demographic or professional) and firms' specific characteristics?

As a practical implication, this research offers managers and other professionals in this field insights to understand the importance of creating long-term relationships and increasing the lifetime value of employees. Employees will better deliver brand promises of the company if they are aware of and familiar with the corporate brand vision (Mitchell, 2002). The future success of companies depends on whether they are able to attract, select, and retain employees with the desired qualifications. Employer productivity is increased when the right type of experiences meet and exceed employees' needs. Successful companies create alliances with employees, meet their human needs, and develop a special connection between the company's goals and employees' needs (Sigmon, 2018).

\section{THEORETICAL BACKGROUND}

\subsection{HR branding versus marketing branding}

Companies have to make extra efforts to maintain their image in order to be perceived by prospective employees as a desirable employer. A company's efforts to attract employees are similar in many ways to efforts made to entice consumers to purchase certain products (Cable \& Turban, 2001).

Just as brand equity plays a crucial role in generating positive affect toward the branded product and defines reasons to choose the brand over its competitors (Aaker, 1996; Keller, 1993), employer branding contributes to maintaining a high level of employer attractiveness on the competitive job market. 
Keller, Apéria \& Georgson (2012) explained the customer-based brand equity model from the perspective of the consumer. The main focus of the model is understanding the needs and wants of the consumer, and hence developing certain products with the right type of experiences to satisfy those needs. Just as the power of a product brand resides in what customer have learned, felt, seen, and heard about the brand, the power of a company brand lies in linking desired employees' thoughts, feelings, images, beliefs, perceptions, and opinions to the company's image. Employer branding is a crucial concept in attracting and retaining employees with superior skills who will align with a defined corporate culture. Employer branding has emerged as a relevant concept, not just for attracting the best talent, but also for nurturing and retaining them for a long time. By investing in talented employees and treating them more like consumers than like employees, companies position themselves as exceptional and reliable corporate brands (Rieches, 2017).

Cable and Turban (2001) suggested that the brand equity concept can be applied during the recruitment processes, so that companies with a desirable image would be preferred over those with weak or negative brand identities. Thus an employer brand is an effective tool for attracting, selecting, and retaining superior employees. Based on Keller's customer-based brand equity model, Kashive \& Khanna, (2017) conceptualized the idea of employer-based brand equity. The employerbased brand equity model suggests that by creating a desirable and favorable company image in employees' minds, employees would prefer a certain company.

The employer-based equity model helps companies to attract, select, and retain internal customers. Brand identity indicates how employees perceive the company and whether they distinguish the company from competitors. Companies with strong employer identity will be perceived as more attractive compared to others. Employee identification with the company has great importance, because employees' attitudes and behaviors could reinforce or weaken the corporate brand (Kashive \& Khanna, 2017). Strong brand meanings should provide a favorable response from an employee when selecting a certain company for which to work. Employees expect to live the company brand they experienced during the recruitment process, and positive feelings will be aroused by assuring the employees of the work experience they perceive.
In the same way that customer-based brand equity explains brand equity from the perspective of the consumer from the attraction stage to the initial purchase to post-purchase behavior and long-term loyalty, employees' perceptions of a company's brand can influence the whole process of attraction, selection, and long-term commitment. The brand image of a company is related to the employees' expectations and the ability of the company to fulfill those expectations. Employer branding affects the employment experience in similar ways that product and branding affects the external customer experience. Consequently, companies can treat potential and current employees as internal customers, because employer branding can be based on the lessons learned from product branding (Wilden, Gudergan, \& Lings, 2010).

Exposed to internal and external stimuli, potential employees seek to determine whether their personal beliefs are consistent with the characteristics of the company. Rogers \& Marcotte (2010) emphasized the importance of $\mathrm{HR}$ branding during the attraction phase in order to communicate the company's main characteristics. By emphasizing the corporate values, companies strive to attain the best employees for certain job positions. Kim \& Sturman, (2012) demonstrated the need to deliver a promised employment experience, motivating and engaging the employee in order to reinforce their loyalty and retention.

\subsection{Components of HR branding}

There are three key components to the HR branding process, and each is integral to obtaining the maximum potential value from an HR brand. These are (1) managing the firm's reputation, (2) managing the firm's culture, and (3) managing the firm's value proposition (Kim, 2012).

Employer branding (managing the firm's reputation). The employer brand puts forth an image showing the organization as a good place to work (Sullivan, 2004). Employer branding has been defined as "a targeted, long-term strategy to manage the awareness and perceptions of employees, potential employees, and related stakeholders with regards to a particular firm" (Sullivan, 2004). Furthermore, Ambler \& Barrow (1996), some of the first to define the term, considered employer branding as "the package of functional, eco- 
nomic and psychological benefits provided by employment, and identified with the employing company." Employer branding impacts organization culture and organization identity, which in turn contribute to employer brand loyalty. Some other recent research proposed that employer branding is the development of an organization's image and reputation as a prospective employer, and affect its ability to retain employees (Sivertzen, Nilsen, \& Olafsen, 2013). Employer branding has been recognized as central for attracting the most valuable employees, as well as maintaining and enforcing the good reputation for the company. Many positive aspects can be acknowledged in the context of employer branding, such as employee's perceived loyalty, retention, satisfaction, and affinity with the employer; and differentiation from other competitor brands (Davies, 2008). Still, employee experiences of the employer brand are significantly different from the ways in which consumers experience products, services, or corporate brands (Moroko \& Uncles, 2008). More companies should understand employer branding, because it is the instrument that allows firms to show how they differentiate themselves from competitors (Ito, Brotheridge, \& McFarland, 2013).

Internal branding (managing the firm's culture). The hype around employer branding has engaged different variables, but largely focuses on the values embedded in the organizational culture. The goal of internal marketing, also known as internal branding, is to cultivate a workforce that is devoted to the set of values and organizational goals established by the firm. In this sense the employer brand should initially be communicated through core values, and it should represent an organization's culture (Backhaus \& Tikoo, 2004). It has been indicated that employer branding helps to manage the right talents by creating an organizational culture and organizational identity (Cable \& Judge, 1997).

However, researchers often tend to consider culture as a context rather than a variable (Smircich, 1983). The culture informs employees how to deliver the service or product in a way that is consistent with the firm's values. The literature also recognizes that once value propositions and brand attributes are acknowledged, the organization should be sure that their organizational culture and brand values are reflected throughout the employer brand (Arachchige \& Robertson, 2013). On the other hand, in terms of attracting the best employees, an organization's culture is important to potential applicants' job preferences. Their beliefs about the firm's culture affect the validity of self-selection decisions (Cable \& Judge, 1996).

\section{Total rewards branding (managing the firm's value} proposition). It has also been suggested that having a competitive reward and benefit program in place can increase organizational success because it has a positive impact on the welfare status of employees, and therefore individuals are more likely to become loyal to the brand (Kucherov \& Zavyalova, 2012). Employers can enhance this by recognizing the areas in which they provide a unique employment experience, looking at the tangible and intangible benefits they offer (Mosley, 2007). One of the main drivers behind the employee's actions is motivation. Organizations regularly assume that their employees perform better if the reward system is attractive (Boel, 2012). This potentially is considered to influence brand loyalty of employees. Organizations follow best human resource practices by handling intangible benefits to create employee loyalty and hence organizational commitment. In essence, to sustain brand standards, an organization should reward employees accordingly, because effective reward and recognition schemes can enhance employee motivation and commitment (Hoffman \& Mehra, 1999). Recruiting, motivating, and rewarding employees are all aspects that can influence the readiness of employees to adopt a new or altered strategic direction with respect to the internal brand (Bergstrom, Blumenthal \& Crothers, 2002). Rewards are an area in which a great number of options are available and in which individuals have different preferences about how they are treated and what they receive. In this sense it should be more than clear that greater compensation attracts more potential candidates, and in this sense, better candidates. Furthermore, it is crucial to communicate the rewards to employees in order to increase a company's reputation.

\subsection{Hypotheses development}

Because the employer branding concept is becoming more important, the necessity of creating strong corporate brand and successfully deliver the corporate branding message to all employees has increased (Aurand, Gorchels, \& Bishop, 2005). Companies must strive to develop a unique and meaningful 
differential effect to provide a competitive advantage so that employees will react more favorably. Brand meaning refers to attitudes held by employees about a certain company that affect their preferences and elicit favorable responses from employees.

A relevant question which arises within this topic is whether there are differences between employees with different demographic or other characteristics in the way they perceived and react to the components of HR branding. In addition, it is very important to understand that not all companies are identical in terms of the environment in which the HR brand can be created, developed, and delivered to the employees. Hence, before investigating any other aspects of HR branding, the possible factors that might affect a company's efforts to create a recognizable HR brand among prospective as well as current employees should be examined.

It is expected that employees at different job position levels could have different perceptions and evaluate with different scores the dimensions of the HR brand of a firm. Employees at different job positions could be different in terms of the total package of economic, functional, and psychological benefits provided by employment. In addition, employees at higher-level positions are those who develop the HR brand dimensions, and who should be more aware of the HR brand and its manifestations, such as brand identification, commitment, loyalty, and brand performance. Finally, the success of delivering the brand massage from the highest to the lowest job positions is very important; therefore, depending on the effectiveness of this process, some differences can be expected between different job positions.

Considering the central role of employees who deliver the output experience in every company, i.e., the product or service, it is also essential that the firm's culture and brands are aligned. Having a culture that is aligned with the service, brand, and product allows a company to deliver differentiated but consistent branded experiences, both tangible and intangible, to external and internal customers alike (Kim \& Sturman 2012). Employees with direct contact with customers, compared with employees with no contact with customers, should be more familiar with, better informed about, better trained in, and have greater awareness of the core values of the corporate brand, because they are in every- day contact with customers and deliver the brand promise to them. Hence, in addition to the two basic characteristics, we added a third, more specific characteristic related to the professional background of respondents, such as job position level and customer contact level.

Based on these three categories of possible factors and the three dimensions of HR branding, we can test many different hypotheses. Because many different variables were created in each of the three categories of factors, only the hypotheses related to the main categories of factors are listed.

\section{Demographic characteristics of respondent (age, gender, and equational level):}

Hypothesis 1a: The distribution of employer branding is different across demographic characteristics of respondents.

Hypothesis $1 b$ : The distribution of internal branding is different across demographic characteristics of respondents.

Hypothesis 1c: The distribution of total awards branding is different across demographic characteristics of respondents.

\section{Professional characteristics of respondent (job level position and customer contact level):}

Hypothesis 2a: The distribution of employer branding is different across professional characteristics of respondents.

Hypothesis $2 b$ : The distribution of internal branding is different across professional characteristics of respondents.

Hypothesis 2c: The distribution of total awards branding is different across professional characteristics of respondents.

Firms characteristics (size, industry sector, and ownership origin):

Hypothesis 3a: The distribution of employer branding is different across firm characteristics.

Hypothesis $3 b$ : The distribution of internal branding is different across firm characteristics.

Hypothesis 3c: The distribution of total awards branding is different across firm characteristics. 


\section{METHODOLOGY}

\subsection{Sample and data collection}

The research was conducted from May to August 2018 , with employees selected at random with different demographics (age, gender, and educational level) and professional characteristics (job level position and customer contact level), and employed in firms with different characteristics (size, industry sector, and ownership origin). Using online survey software and social media, the questionnaire was distributed online; 330 responses were collected, a response rate of $65 \%$. This provided a rich sample with various backgrounds and various employees.

The questionnaire was composed of separate sections related to specific dimensions of HR branding, such as employer branding, internal branding, and total rewards branding, as well as a section related to possible factors that might affect HR branding. The analysis was based upon latent constructs which were not directly measured, but, using connected indicators explaining the main variables, measured through a Likert-type scale with five points. The first dimension of HR branding, employer branding, was measured using the measurement scale developed by Schlager at al. (2011). The measurement scale includes 24 indicators divided into five subdimensions: economic value, development value, social value, diversity value, and reputation value. The second dimension of HR branding, internal branding, was measured using the measurement scale developed by Punjaisri \& Wilson (2010). The measurement scale includes 15 indicators divided into four subdimensions of internal branding outputs: brand identification, brand commitment, brand loyalty, and brand performance. The third dimension of HR branding, total rewards branding, was measured using the measurement scale developed by Vandenberghe at al. (2008). The measurement scale includes eight factors comprising the three major types of compensation: (1) direct compensation, (2) indirect pay, and (3) psychological recognition (or intrinsic recognition). The total score of each HR branding dimension was calculated as a mean of the values appointed for each of the items measured on a five-point scale.

As mentioned previously, the other parts of the measurement instrument consisted of questions regarding factors that might affect HR branding. For gen- der, a dummy variable was created, and the respondents were divided into two groups: male and female. Age was measured on an ordinal scale with six categories (18-21, 22-29, 30-39, 40-49, 50-59, and 60 or more years). Educational level was measured on an ordinal scale with three categories (secondary education, high education, and master's or doctoral degree). Job level position was measured on an ordinal scale with three categories (non-managerial positions, lower management positions, and middle and top management positions). Customer contact level was measured on an ordinal scale with three categories (no contact, partial contact, and direct contact). Firm size was measured on an ordinal scale with three categories (small, medium, and large firms). Industry sector was measured on a categorical scale with three categories (production, trade, and services and other sectors). For ownership origin, a dummy variable was created with two groups: domestic and foreign firms.

In order to test reliability of the proposed scales on the research sample of this study, Cronbach's alpha was calculated as well. Cronbach's alpha indicates that the overall reliability of a measurement scale is considered to be good when it is above 0.7. In this case, $\alpha$ was above 0.7 , indicating good reliability (Table 1 ).

\section{Table 1: Cronbach's alpha of latent variables}

\begin{tabular}{|l|c|}
\hline Latent variable & Cronbach's $\alpha$ \\
\hline Employer branding & 0.957 \\
\hline Internal branding & 0.929 \\
\hline Total rewards branding & 0.861 \\
\hline
\end{tabular}

Different parametric and non-parametric tests were run to determine if there were group differences in employer branding, internal branding, and total rewards branding scores between groups within eight evaluated variables divided into three categories: demographics of respondents (age, gender, and educational level), firm characteristics (size, industry sector, and ownership origin), and professional characteristics of respondents (job level position and customer contact level).

The independent-samples t-test and MannWhitney $U$ test were used to determine if differences existed between two different groups in 
terms of gender and ownership origin in terms of HR branding dimensions. In addition to the fact that the data did not pass the test of normality, we used this method because the independent-samples ttest is considered "robust" to violations of normality. This means that some violation of this assumption can be tolerated and the test will still provide valid results. This test requires only approximately normal data. Furthermore, as sample size increases, the distribution can be very non-normal, but because of the central limit theorem, the independent-samples t-test can still provide valid results. Furthermore, if the distributions are all skewed in a similar manner (e.g., all moderately negatively skewed), this is not as troublesome as the situation in which groups have differently shaped distributions. We ran the Mann-Whitney $\mathrm{U}$ test in order to confirm and strengthen the validity of the results and inferences obtained either with parametric or non-parametric methods.

The one-way ANOVA and Kruskal-Wallis $\mathrm{H}$ test were run to determine if differences existed in terms of HR branding dimensions between three or more different groups in each of the following variables: age, educational level, size, industry sector, job level position, and customer contact level. Because the data were not normally distributed, but the distributions were all skewed in a similar manner (all moderately negatively skewed), we ran both parametric and non-parametric tests in order to confirm and strengthen the validity of the results and inferences.

\section{RESULTS}

Different parametric and non-parametric tests were run to determine if there were group differences in the three dimensions of HR branding - employer branding, internal branding, and total rewards branding - between groups within the eight evaluated factors divided into three categories: demographics of respondents, firm characteristics, and professional characteristics of respondents.

Because many different variables were tested to discover any statistically significant difference in evaluated HR branding dimensions and many analyses with numerous outputs were conducted, but the results revealed statistically significant differences only between employees within the third category of variables (professional characteristics: job level position and customer contact level), this section analyzes these two variables.

A Kruskal-Wallis $\mathrm{H}$ test was run to determine if there were differences in employer branding, internal branding, and total rewards branding scores between three groups of participants with different job position levels: non-managerial positions, lower management positions, and middle and top management.

Distributions of employer branding, internal branding, and total rewards branding scores were similar for all groups (non-managerial positions, lower management positions, and middle and top management), as assessed by visual inspection of boxplots. The descriptive statistics of job level position are presented in Table 2.

Table 2: Descriptive statistics - Job position level median values

\begin{tabular}{|l|l|c|c|c|}
\hline \multicolumn{2}{|l|}{ Job level position } & Employer branding & Internal branding & Total rewards branding \\
\hline \multirow{2}{*}{ Non-managerial level } & Median & 3.7083 & 3.8667 & 3.5000 \\
\cline { 2 - 5 } & $\mathrm{N}$ & 145 & 145 & 145 \\
\hline \multirow{3}{*}{ Lower-level management } & Median & 3.8750 & 4.0667 & 3.8750 \\
\cline { 2 - 5 } & $\mathrm{N}$ & 92 & 92 & 92 \\
\hline \multirow{2}{*}{ Middle- and top-level management } & Median & 4.0417 & 4.2667 & 4.0000 \\
\cline { 2 - 5 } & $\mathrm{N}$ & 93 & 93 & 93 \\
\hline \multirow{2}{*}{ Total } & Median & 3.8333 & 4.0667 & 3.7500 \\
\cline { 2 - 5 } & $\mathrm{N}$ & 330 & 330 & 330 \\
\hline
\end{tabular}


Stojan Debarliev, Ezeni Brzovska, Aleksandra Janeska - Iliev: HR Branding and The Potential Value: Empirical Evidence and Practical Implications

The result was statistically significant for all three HR branding dimensions, so we reject the null hypotheses and accept the alternative hypotheses. Median employer branding scores were statistically significantly different between groups: $\mathrm{H} 2 \mathrm{a}=$
$12.074, \mathrm{p}<0.001$. Median internal branding scores were statistically significantly different between groups: $\mathrm{H} 2 \mathrm{~b}=17.167, \mathrm{p}<0.001$. Median total rewards branding scores were statistically significantly different between groups: $\mathrm{H} 2 \mathrm{c}=20.254, \mathrm{p}<0.001$

Table 3: Hypothesis test summary - Job position level

\begin{tabular}{|c|l|c|c|c|}
\hline $\mathbf{1}$ & Hypothesis & \multicolumn{1}{|c|}{ Test } & Sig. & Decision \\
\hline $\mathbf{2}$ & $\begin{array}{l}\text { The distribution of employer branding is different across categories of } \\
\text { job position level. }\end{array}$ & $\begin{array}{l}\text { Independent-samples } \\
\text { Kruskal-Wallis test } \\
\text { position level. }\end{array}$ & $\begin{array}{c}\text { Accept the } \\
\text { hypothesis. }\end{array}$ \\
\hline $\mathbf{3}$ & $\begin{array}{l}\text { The distribution of total reward branding is different across categories } \\
\text { of job position level. }\end{array}$ & $\begin{array}{l}\text { Independent-samples } \\
\text { Kruskal-Wallis test }\end{array}$ & $\begin{array}{c}\text { Accept the } \\
\text { hypothesis. }\end{array}$ \\
\hline Asymptotic significances are displayed. The significance level is 0.10. & $\begin{array}{c}\text { Accept the } \\
\text { hypothesis. }\end{array}$ \\
\hline
\end{tabular}

Pairwise comparisons were performed using Dunn's (1964) procedure with a Bonferroni correction for multiple comparisons. Adjusted p-values are presented. This post hoc analysis revealed statistically sig- nificant differences in median employer branding scores between the non-managerial positions (3.71) and middle and top management positions (4.04) $(p=$ $0.002)$, but not between any other group combination.

Table 4: Pairwise comparisons of job position level for employer branding

\begin{tabular}{|l|c|c|c|c|c|}
\hline Sample1-Sample2 & Test statistics & Std. error & Std. test statistic & Sig. & Adj. sig. \\
\hline Non-managerial-Lower management level & $(15.020)$ & 12.714 & $(1.181)$ & 0.237 & 0.712 \\
\hline Non-managerial-Middle and top management level & $(49.972)$ & 12.672 & $(3.470)$ & 0.001 & 0.002 \\
\hline Lower management-Middle and top management level & $(28.952)$ & 14.026 & $(2.064)$ & 0.039 & 0.117 \\
\hline
\end{tabular}

Furthermore, the post hoc analysis revealed statistically significant differences in median internal branding scores between the non-managerial positions (3.87) and middle and top management posi- tions (4.27) $(p=0.000)$, and between lower management positions (4.07) and middle and top management positions (4.27) ( $p=0.087)$.

Table 5: Pairwise comparisons of job position level for internal branding

\begin{tabular}{|l|c|c|c|c|c|}
\hline Sample1-Sample2 & Test statistics & Std. error & Std. test statistic & Sig. & Adj. sig. \\
\hline Non-managerial-Lower management level & $(21.834)$ & 12.709 & $(1.718)$ & 0.086 & 0.257 \\
\hline Non-managerial-Middle and top management level & $(52.464)$ & 12.667 & $(4.142)$ & 0.000 & 0.000 \\
\hline Lower management-Middle and top management level & $(30.629)$ & 14.021 & $(2.185)$ & 0.029 & 0.087 \\
\hline
\end{tabular}

Finally, the post hoc analysis revealed statistically significant differences in median total rewarding scores between the non-managerial (3.50) and lower management (3.88) $(p=0.054)$, and between non-managerial (3.50) and middle and top management $(4.00)(p=0.000)$. 
Table 6: Pairwise comparisons of job position level for total rewards branding

\begin{tabular}{|l|c|c|c|c|c|}
\hline Sample1-Sample2 & Test Statistics & Std. Error & Std. Test Statistic & Sig. & Adj. Sig. \\
\hline Non-managerial-Lower management level & $(30.083)$ & 12.701 & $(2.369)$ & 0.018 & 0.054 \\
\hline Non-managerial-Middle and top management level & $(56.295)$ & 12.659 & $(4.447)$ & 0.000 & 0.000 \\
\hline Lower management-Middle and top management level & $(26.211)$ & 14.001 & $(1.871)$ & 0.061 & 0.184 \\
\hline
\end{tabular}

A Kruskal-Wallis $\mathrm{H}$ test was run to determine if there were differences in employer branding, internal branding, and total rewards branding scores between three groups of participants with different customer contact levels: direct contact, partial contact, and no contact.
Distributions of employer branding, internal branding, and total rewards branding scores were similar for all groups (direct contact level, partial contact level, and no contact level), as assessed by visual inspection of a boxplot.

The descriptive statistics of Customer contact level are presented in Table 7.

Table 7: Descriptive statistics - Customer contact level median values

\begin{tabular}{|l|l|c|c|c|}
\hline \multicolumn{2}{|l|}{ Customer contact level } & Employer branding & Internal branding & Total rewards branding \\
\hline \multirow{2}{*}{ Direct customer contact } & Median & 3.9583 & 4.1333 & 3.7500 \\
\cline { 2 - 5 } & N & 201 & 201 & 201 \\
\hline \multirow{2}{*}{ Partial customer contact } & Median & 3.7083 & 4.0000 & 3.6250 \\
\hline \multirow{2}{*}{ No customer contact } & N & 84 & 84 & 84 \\
\hline \multirow{2}{*}{ Total } & Median & 3.7083 & 3.7333 & 3.5000 \\
\cline { 2 - 5 } & $\mathbf{N}$ & 45 & 45 & 45 \\
\hline & Median & 3.8333 & 4.0667 & 3.7500 \\
\cline { 2 - 5 } & $\mathbf{N}$ & 330 & 330 & 330 \\
\hline
\end{tabular}

Table 8 shows that the result was statistically significant for two HR branding dimensions, so we reject the null hypotheses and accept the alternative hypotheses. Median employer branding scores were statistically significantly different between groups: $\mathrm{H} 2 \mathrm{a}=4.788, \mathrm{p}<0.091$. Median internal branding scores were statistically significantly different between groups: $\mathrm{H} 2 \mathrm{~b}=11.800, \mathrm{p}<0.001$.

Table 8: Hypothesis test summary - Job level position

\begin{tabular}{|c|c|c|c|c|}
\hline & Hypothesis & Test & Sig. & Decision \\
\hline 1 & $\begin{array}{l}\text { The distribution of employer branding is different across } \\
\text { categories of customer contact level. }\end{array}$ & $\begin{array}{l}\text { Independent-samples } \\
\text { Kruskal-Wallis test }\end{array}$ & 0.091 & Accept the hypothesis. \\
\hline 2 & $\begin{array}{l}\text { The distribution of internal branding is different across } \\
\text { categories of customer contact level. }\end{array}$ & $\begin{array}{l}\text { Independent-samples } \\
\text { Kruskal-Wallis test }\end{array}$ & 0.003 & Accept the hypothesis. \\
\hline 3 & $\begin{array}{l}\text { The distribution of total reward branding is different across } \\
\text { categories of customer contact level. }\end{array}$ & $\begin{array}{l}\text { Independent-samples } \\
\text { Kruskal-Wallis test }\end{array}$ & 0.308 & Reject the hypothesis. \\
\hline \multicolumn{5}{|c|}{ Asymptotic significances are displayed. The significance level is 0.10 . } \\
\hline
\end{tabular}


Stojan Debarliev, Ezeni Brzovska, Aleksandra Janeska - Iliev: HR Branding and The Potential Value: Empirical Evidence and Practical Implications

Pairwise comparisons were performed using Dunn's (1964) procedure with a Bonferroni correction for multiple comparisons. Adjusted $p$-values are presented. This post hoc analysis revealed statisti- cally significant differences in median internal branding scores between the no contact level (3.73) and the direct contact level $(4.13)(p=0.002)$, but not between any other group combination.

Table 9: Pairwise comparisons of customer contact level for internal branding

\begin{tabular}{|l|c|c|c|c|c|}
\hline Sample1-Sample2 & Test statistics & Std. error & Std. test statistic & Sig. & Adj. Sig. \\
\hline No customer contact-Partial customer contact & 36.334 & 17.614 & 2.063 & 0.039 & 0.117 \\
\hline No customer contact-Direct customer contact & 53.205 & 15.725 & 3.384 & 0.001 & 0.002 \\
\hline Partial customer contact-Direct customer contact & 16.871 & 12.338 & 1.362 & 0.173 & 0.520 \\
\hline
\end{tabular}

\section{DISCUSSION AND CONCLUSION}

The results show that there were no statistically significant differences considering employer branding, internal branding, and total rewards branding scores between groups within the first and the second categories of variables, related to the demographics of respondents (age, gender, and educational level) and firm characteristics (size, industry sector, and ownership origin), respectively.

These results in particular mean that there was no difference in any of the three evaluated HR branding dimensions between male and female employees at different ages or with any educational degree (secondary education, higher education, and master's or doctoral degree). We expected that possible differences could occur among the employees as age increased, i.e., older employees who have greater work experience should be more involved in organizational life, more familiar with the organizational culture, and more connected with the organizational identity. In addition, some differences were expected between male and female employees. Female employees are more likely to demonstrate higher scores in internal branding because this dimension concerns the organizational culture, values, and beliefs that are more related to the traditionally higher emotional intelligence of the female population. On the other hand, male employees are more expected to manifest a higher score in total rewarding (especially in the quantitative items of this dimension), because of the traditional gender pay gap in favor of the male population. Furthermore, employees with a higher educational level are more likely to demonstrate greater understanding and recognition of HR branding dimensions and thus to highly evaluate these dimensions, or if a HR brand is negative, to be more rigorous in their perceptions and evaluations.

The results also show that there is no difference in any of the three evaluated HR branding dimensions between employees from firms with different characteristics, such as small, medium, or large firms; firms that operate in production, trade, or services and other sectors; and between domestic and foreign firms. We expected to find differences in some of the variables. It was expected that large firms would have more developed company images and identities, and that if the message of the company brand is appropriately delivered internally, employees in large firms would demonstrate higher scores in HR branding. In addition, in firms that operate in sectors which are typically more customeroriented, such as trade and services, employees were more likely to be familiar with the corporate brand in order to more successfully deliver the brand promise to their customers. Finally, the most probable difference was expected among the employees in foreign versus domestic firms. It is probable that foreign companies have more developed $\mathrm{HR}$ brands and the perceptions and evaluations of employees in these companies result in higher HR branding scores.

Finally, the results confirmed the expected differences in some of the evaluated HR branding dimensions between employees with different 
professional characteristics (job level position and customer contact level). In particular, for the first variable in this category (job level positon), the results revealed statistically significant differences in all three HR branding dimensions: employer branding (between non-managerial positions and middle and top management positions), internal branding (between non-managerial positions and middle and top management positions and between lower management positions and middle and top management positions), and total rewarding (between non-managerial positions and lower management positions and between non-managerial positions and middle and top management positions).

The difference in HR branding between the different job level positions is obvious, especially from the lower to the higher levels. Higher-level positions tend to have better perceptions and gave higher scores to the HR brand of the firm. There might be three possible explanations for this. First, employees at this level hold better job positions in terms of the total package of economic, functional, and psychological benefits provided by employment. Consequently, these employees better perceive and evaluate the HR brand. Second, the higher-level positions are those that create the HR brand, are more aware of its manifestations, and probably perceive the HR brand more highly. Third, in addition to the $\mathrm{HR}$ brand being well developed, it is necessary to successfully deliver the corporate brand message to all employees. In this regard, Kim and Sturman (2012) demonstrated the need to deliver a promised employment experience, motivating and engaging the employees in order to reinforce their loyalty and retention.

For the second variable in this category (customer contact level), the results revealed statistically significant differences only for one of the three dimensions. There was a statistically significant difference in internal branding between the "no contact" employees and the "direct contact" employees in terms of the frequency of their everyday contact with the customers of the firm. Hence, the questions that arise are related to the internal branding issues and their interpretation are relevant for discussion. Concerning the internal branding, among the other questions, the employees evaluated their commit- ment and performance to deliver the company brand to customers, such as: 'My commitment to deliver the brand increases along with my knowledge about the brand," "I am very committed to delivering the brand promise to our customers," and "I always handle customers' specific requests within a standard set for the brand." Hence, the employees in the "direct contact with customers" group versus the "no contact with customers" group are more likely to be more aware of, knowledgeable about, qualified in, and to have greater responsiveness for the core values of the corporate brand, because they are in frequent contact with the customers in delivering the brand promise to them. In this regard, a very important role of organizational culture is to inform employees how to deliver the service or product in a way that is consistent with the firm's values. The goal of internal marketing, also known as internal branding, is to cultivate a workforce that is devoted to the set of values and organizational goals established by the firm. Having a culture that is aligned with the service brand and product allows a company to deliver differentiated but consistent branded experiences, both tangible and intangible, to external and internal customers alike (Kim \& Sturman 2012).

Investigating whether there are differences in $H R$ branding dimensions among employees and firms based on their specific characteristics, this research confirmed the second specific research question regarding differences in $H R$ branding dimensions among employees based on the professional characteristics of employees. In particular, for the first variable in this category (job level positon), the results revealed statistically significant differences in all three HR branding dimensions, and for the second variable in this category (customer contact level), the results revealed statistically significant differences only for one of the three dimensions (internal branding).

Creating long-term relationships and increasing the lifetime value of the employees is a management and organizational process that requires considerable effort, commitment, and persistence, with a holistic approach of different actors and components. The process begins with building an HR brand with strong employer identity as well as an image and reputation as a desirable employer. This can be 
done by delivering a unique employment experience as a package of functional, economic, and psychological benefits provided by employment. Once the HR brand has been developed, the necessity to deliver the corporate brand message to all employees is increased. An employer brand should be communicated through an organization's core culture and values. In the second phase of the process, the goal of internal marketing, also known as internal branding, is to develop and articulate the firm's unique culture, because it helps employees to live the brand, i.e., to live by the firm's core internal values. Very important in this phase is the role of culture to inform employees how to deliver the product brand promise in a way that is consistent with the firm's values. It is also essential that the firm's culture and brands are aligned. Consequently, as an instrumental result, the employees have awareness of, positive associations with, and preferences for companies which have respectable corporate brand images. Many positive ultimate results in the context of employer branding can arise, such as employee commitment, loyalty, performance, attraction, and retention; as well as differentiation from competitor brands. Finally, employer productivity will increase when the promised employment experience meets and exceeds employees' employment expectations.

Future research should examine links between employees' perceptions of the dimensions of HR branding and different employee outputs, such as identification, commitment, loyalty, and performance.

\section{EXTENDED SUMMARY / IZVLEČEK}

Akademske raziskave na področju blagovne znamke delodajalca so kljub naraščujoči priljubljenosti koncepta precej omejene. Pričujoči članek predstavlja ključno in pionirsko raziskavo v Republiki Severni Makedoniji. Raziskuje možne dejavnike, ki bi lahko vplivali na specifične razsežnosti blagovne znamke podjetja, kot so trženje blagovne znamke delodajalca, notranja blagovna znamka in trženje strategije nagrajevanja. Za preverjanje razlik med skupinami dejavnikov so avtorji uporabili osem ocenjevalnih spremenljivk, razdeljenih na tri kategorije: demografija anketirancev (starost, spol in stopnja izobrazbe), značilnosti podjetja (velikost, panoga in izvor lastništva) in poklicne značilnosti anketirancev (raven delovnega mesta in stopnja stikov s strankami). S pomočjo slednjih so izvedli različne parametrične in neparametrične teste. Rezultati potrjujejo pričakovane razlike $v$ nekaterih ocenjenih razsežnostih blagovne znamke podjetja med zaposlenimi na različnih delovnih mestih (stopnja zaposlitve in stopnja stikov s strankami).

\section{REFERENCES}

Aaker, D. A. (1996). Measuring brand equity across products and markets. California management review, 38(3), pp. 102-120.

Ambler, T., \& Barrow, S. (1996). The employer brand. Journal of brand management, 4(3), pp. 185-206.

Arachchige, B.J., \& Robertson, A. (2013). Employer Attractiveness: Comparative Perceptions of Undergraduate and Postgraduate Students. Sri Lankan Journal of Human Resource Management, 4(1), pp. 33-48.
Aurand, T. W., Gorchels, L., \& Bishop, T. R. (2005). Human resource management's role in internal branding: an opportunity for cross-functional brand message synergy. Journal of Product \& Brand Management, 14(3), pp. 163-169.

Backhaus, K. \& Tikoo, S., 2004. Conceptualizing and researching employer branding. Career development international, 9(5), pp. 501-517.

Bergstrom, A., Blumenthal D. \& Crothers S. (2002). Why internal branding matters: the case of Saab. Corporate Reputation Review, 5(2/3), pp. 133-42. 
Boel, R. (2012). The individual differences in motivation and the perception of money importance. MSc Theses in Business Studies at the University of Amsterdam.

Cable, D. M. \& Judge T.A. (1997). Interviewers Perceptions of Person-Organization Fit and Organizational Selection Decisions. Journal of Applied Psychology, 82, pp. 546-561.

Cable, D. M., \& Turban, D. B. (2001). Establishing the dimensions, sources and value of job seekers' employer knowledge during recruitment. Research in personnel and human resources management, pp. 115-163.

Davies, G. (2008). Employer branding and its influence on managers, European Journal of Marketing, 42(5/6), pp. 667-681.

Dunn O. J. (1964). "Multiple comparisons using rank sums." Technometrics, 6, pp. 241-252.

Enz, C. (2001). What keeps you up at night? Key issues of concern for lodging managers. Cornell Hotel and Restaurant Administration Quarterly, 42 (2), pp. 38-45.

Hoffman, J. \& Mehra, S. (1999). 'Operationalizing productivity improvement programs through total quality management', The International Journal of Quality \&Reliability Management, 16 (1), pp. 72-90.

Ito, J., Brotheridge, C.M., \& McFarland, K. (2013). Examining how preferences for employer branding attributes differ from entry to exit and how they relate to commitment, satisfaction, and retention. Career Development International, 18(7), pp. 732-752.

Kashive, N., \& Khanna, V. T. (2017). Conceptualizing Employer-Based Brand Equity and Employer Brand Pyramid. European Scientific Journal, ESJ, 13(34).

Keller, K. L. (1993). Conceptualizing, measuring, and managing customer-based brand equity. The Journal of Marketing, 57(1), pp. 1-22.

Keller, K. L., Apéria, T., \& Georgson, M. (2012). Strategic brand management: A European perspective. Pearson Education.

Khan, B. (2009). Internal branding: aligning human capital strategy with brand strategy, Journal of Brand Management, 6, pp. 22-36.

Kim, D., \& Sturman, M. C. (2012). HR branding: How human resources can learn from product and service branding to improve attraction, selection, and retention. Cornell Hospitality Report, 12(14), pp. 6-17.

Kryger A. H., Esmann A. S., \& Thomsen, C. (2011). Conceptualising employer branding in sustainable organisations. Corporate Communications: An International Journal, 16(2), pp. 105-123.

Kucherov, D., \& Zavyalova, E. (2012). HRD practices and talent management in the companies with the employer brand. European Journal of Training and Development, 36(1), pp. 86-104.
Leekha C. N., \& Sharma, S. (2014). Employer branding: strategy for improving employer attractiveness. International Journal of Organizational Analysis, 22(1), 48-60.

Mitchell, C. (2002). Selling the brand inside. Harvard business review, 80(1), pp. 99-101.

Moroko, L., \& Uncles, M. D. (2008). "Characteristics of successful employer brands". Journal of Brand Management, 16(3), pp. 160-175.

Mosley, R. (2007). "Customer experience, organizational culture and the employer brand", Journal of Brand Management, 15(2), pp. 123-134.

Peters, T. (1999): "The Brand You 50: Fifty Ways to Transform Yourself from an Employee into a Brand that Shouts Distinction, Knopf Publishers", New York, NY.

Punjaisri, K., \& Wilson, A. (2011). Internal branding process: key mechanisms, outcomes and moderating factors. European Journal of Marketing, 45(9/10), pp. 1521-1537.

Rieches, R. (2017). Brand: Building from the inside out, BrandingBusiness, Retrieved from http://www.brandingbusiness.com

Rogers, S. and Marcotte, S. (2010). Communicating Total Rewards. AZ: WorldatWork Press. CA.

Sigmon, J. (2018), Reimagining the Future of Work and HR with Connection in Mind, Forbes, Retrieved from https://www.forbes.com

Sivertzen, A., Nilsen, E.R., \& Olafsen, A.H. (2013). Employer branding: Employer attractiveness and the use of social media, Journal of Product \& Brand Management, 22(7), pp. 473-483.

Smircich, L. (1983), Concepts of culture and organizational analysis, Administrative Science Quarterly, 28, pp. 339-58.

Sullivan, J. (2004). Eight elements of a successful employment brand, ER Daily, Retrieved from www.erexchange.com

Vandenberghe, C., St-Onge, S., \& Robineau, É. (2008). An analysis of the relation between personality and the attractiveness of total rewards components. Relations Industrielles/Industrial Relations, 63(3), pp. 425-453.

Wilden, R., Gudergan, S. \& Lings, I. (2010). Employer branding: strategic implications for staff recruitment. Journal of Marketing Management, 26(1-2), pp. 56-73. 